\title{
16. Passionate defenders, accidental leaders: Women in the Australian environment movement
}

\author{
Jane Elix ${ }^{1}$ and Judy Lambert ${ }^{2}$
}

The environment movement, like many other social change movements, is not easy to define or delineate. Individuals within a movement may hold extremely diverse views on goals, strategies and even philosophies, but 'a shared sense of moral outrage ${ }^{3}$ builds alliances within and between the different organisations that form part of the environment movement.

Women have been active in seeking protection of the environment since Federation and even before 1900. Those in the historical record include Georgiana Molloy (1805-43) and Elizabeth Gould (1804-41), both of whom played a significant role in supporting the scientific endeavours of their male colleagues, while Jane Franklin (1791-1875), Ellis Rowan (1847-1922) and Amalie Dietrich (1821-91) were explorers and scientific adventurers in their own right. We might fairly assume that other endeavours went quietly unrecorded. After them came a string of women who were enthusiastic bushwalkers, either with other women (Ethel Lun and her two friends) or in mixed company (Marie Byles, Dorothy Butler, Jessie Luckman and Hattie Clark).

This particular research on female environment movement leaders is built around interviews with 34 women who have filled leadership roles in the movement since its emergence in the 1970s as a force for social change. The interviewees, subject to their availability, were selected to provide a representative sample from across the spectrum of organisations and their locations that together make up the Australian environment movement. The sample captures the views of women of different ages, backgrounds and interests who have filled a diversity of roles within the movement. The interviews were conducted throughout 2011 , each completed using a semi-structured set of questions as a starting point for a broader-ranging discussion. Wherever possible, the interviews were held in

\footnotetext{
1 Formerly Jane Elix Consulting and The Australian National University. Jane Elix conducted the research and prepared an initial overview of this chapter in 2011. In December 2011 Jane became seriously ill and was unable to complete the project. She briefed her friend and former business partner Judy Lambert, who took up the challenge of completing Jane's commitment to the project. The work is a tribute to Jane, who passed away in July 2012, and whose own contribution to leadership by and mentoring of women in the environment movement is worthy of powerful recognition.

2 Community Solutions.

3 Drew Hutton and Libby Connors, A History of the Australian Environment Movement (Melbourne: Cambridge University Press, 1999), 5.
} 
the home of the interviewee, or within the region that was the focus of their involvement in the environment movement. The personal stories of these women and their relationships to wider perspectives on leadership guide this chapter.

Consistent with the findings of Drew Hutton and Libby Connors, the environment movement has a different meaning for almost every person interviewed. ${ }^{4}$ So, in using the term 'Australian environment movement', this research focused on the work of leaders in organisations that

- have originated in Australia; or

- have been embedded in Australia for a long time and have a specific Australian identity

- have a clearly stated objective of changing political and industry policies and practices on environmental protection and management

- have a membership base of either individuals or organisations (the latter being peak bodies).

Generally not included are women in

- organisations whose principal activities are education, scientific investigation, recreation, networking and information exchange or planning

- organisations which have a very recent presence in Australia, but whose bases lie overseas.

Many of the women leaders who have been part of this project have moved between organisations that fit the four criteria above and those that do not. While there are many other women who meet these criteria for leadership, the intention of this research was to gather a representative sample of environmental leadership across the decades since Federation.

\section{Defining leadership}

Definitions of leadership vary widely over time and context. Amanda Sinclair, in her rethinking of leadership, describes it as 'a relationship, in which leaders inspire and mobilise others to extend their capacity to imagine, think and act in positive new ways'. ${ }^{5}$ She goes on to stress that leadership is not a weighty responsibility usually borne by men and played out through the individual performances of interlocking elites. 'Leadership is not a job or a position, but a way of influencing others towards ends recognised as valuable and fulfilling. ${ }^{6}$

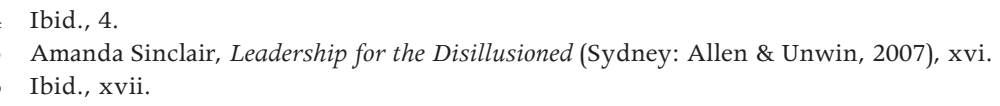


While many women in the environment movement have sought an inclusive, collaborative approach to leadership, ample evidence exists suggesting that many remain bound by societal expectations aligned with a more directive leadership style usually associated with men.

\section{Leadership styles}

Participatory democracy was a catchcry of social change in the 1960s. Carol Mueller identifies three key elements of this early push for 'participatory democracy': 1) grassroots involvement in decision-making; 2) minimisation of hierarchy 'with expertise and professionalism as a basis for leadership'; and 3) a call for direct action. ${ }^{7}$ In the preceding chapter, Marian Sawer and Merrindahl Andrew identify the hopes and expectations of feminism of the 1970s that hierarchical male-dominated leadership styles would be replaced with a new collective-based approach in which functions were shared democratically within the organisation or group. This change in leadership was expected to replace male management or leadership styles in business, in government, in politics and in the non-governmental (third) sector. Areas of social change that held similar or complementary values, including in the environment movement, were expected to become part of this change.

Male styles were described as 'command and control, using organisational status and manipulation of rewards' and called transactional. In contrast, Judy Rosener and others describe the female collaborative approach as transformational, 'enhancing other people's sense of self-worth and energizing followers' ${ }^{8}$

Sinclair describes, however, how over recent decades 'transformational leadership' has been adopted by mainstream leadership trainers and gurus. 'A sizable genre of leadership writing, from the 1980s through to the present, pines after leadership that is fused with goodness, caring and a "servant" mentality." In this literature, the 'transformational' leadership model has been linked not to the outcomes that are envisaged by feminists, but rather to the capitalist values of large material achievement, competition and conquest. The transformational model of leadership has been coopted and corrupted by what Sinclair refers to as 'McDonaldized leadership'.

Sinclair identifies an important place for charisma in leadership in recent times. Like leadership, charisma may derive from a diversity of qualities that inspire

7 Carol Mueller, 'Ella Baker and the Origins of "Participatory Democracy"', in The Black Studies Reader, eds Jaqueline Bobo, Cynthia Hudley and Claudine Michel (New York: Routledge, 2004), 79.

8 Judy R. Rosener, 'Ways Women Lead', Harvard Business Review (November-December 1990): 122, Reprint No. 90608, 4.

9 Sinclair, Leadership for the Disillusioned, 24. 
others. Dennis Perkins and his colleagues in their examination of leadership based on Antarctic explorer Ernest Shackleton emphasise the importance of optimism in the charismatic leader. ${ }^{10}$ In the environment movement, high value is placed on charismatic leadership - for men at least - and allowances are made for charismatic leaders who can inspire optimism even when they are not good managers. It is not unusual for a male leader to surround himself with women with high interpersonal skills to buttress his organisational roles.

\section{'Male' leadership in the environment movement}

The language attached to male-dominated 'command and control' transactional leadership and its contrast with the more collaborative transformational leadership style posed as an alternative may seem simplistic and bound to stereotypes that feminism was seeking to overcome; however, when asked about differences between men's and women's leadership in the environment movement, the language used by many of those interviewed reflects these characteristics of female and male leadership.

Margaret Blakers commented that ' $[\mathrm{m}] \mathrm{en}$ are more prepared to put themselves in the front row of representing the group or being recognised. And that's society's expectation too, I think it's very deeply embedded-still.'

This is a view reinforced by comments from Brigid Dowsett: 'Women come in hoping and believing that the environment movement is going to be differentless hierarchical - but in the end it's really no different from the way the rest of society functions.'

Hannah Aulby, a much younger environmental leader, says: 'Women push their agenda along a bit more quietly and carefully ... It's hard to generalise, but men are maybe a bit less conscious of the consequences of their decisions, more single focused, more focused on the few things that they've decided to pursue.'

This male model may be changing, according to Louise Crossley:

Increasingly the concept of leadership of being out front and having everyone else follow is not the way it works. Usually two or three brains are better than one, and it's that kind of collaborative leadership that works best, and the sum becomes greater than the parts, and that's the excitement of it.

10 Dennis Perkins, Margaret Holtman, Paul R. Kessler and Catherine McCarthy, Leadership at the Edge: Leadership Lessons from the Extraordinary Saga of Shackleton's Antarctic Expedition (New York: AMACOM, 2000). 
The leadership that women are quite good at is cooperative, collegial and it's not leadership by command.

\section{Barriers to women's leadership}

That the concept of 'leadership' is problematic for many women from the environment movement is perhaps one of the barriers to their greater uptake of traditional leadership roles. When interviewed, many expressed views such as 'I never thought of myself as a leader'. Few stepped forward to claim identified leadership roles. Most who took on such roles did so only after being persuaded by others.

Typifying this pathway is Beth Schultz (b. 1936), who for the past 36 years has worked in a voluntary leadership capacity for the WA environment movement, many of those years as chair of the WA Conservation Council. Beth is now an icon for younger women environmentalists, but her comments still reflect a discomfort with the label of leadership. 'I've never thought of myself as a leader-you don't put yourself out there-it just happens. You wait to be invited or there's nobody else doing it.' To this reluctance can be added the influence of family circumstances. Among the almost three-quarters of interviewees currently in a long-term relationship, support from partners varied across the spectrum from working together in an organisation and extensive support and encouragement to partner perceptions of commitment to environmental campaign jobs as being 'selfish', with little support being provided in household activities and caring for children.

The challenges of juggling environmental leadership roles and caring for children were a significant factor for many interviewees. Some chose to take up more local roles so they could spend time with children and for others this challenge was identified as a factor contributing to the breakdown of marriage or long-term relationships.

Of the women interviewed, 14 (41 per cent) were childless by choice or circumstance, and none had four or more children. Each of these is a significantly higher proportion than in the general population. ${ }^{11}$ For some, this was a deliberate choice made for environmental reasons. For others, it was a response to a perceived need 'to make a choice in life'. One interviewee captured the sentiment of others in her comment that '[t]he challenge is trying to incorporate the nurturing, family-oriented role that most women aspire to with the focus that you've got to have if you're really trying to make a difference'.

11 Australian Bureau of Statistics (ABS), Australian Social Trends, ABS Publication 4102.0 (Canberra: Australian Bureau of Statistics, 2008). 
Diversity in Leadership: Australian women, past and present

\section{Conditions under which women have assumed leadership}

Since the nineteenth century, when an interest in the natural sciences was the preserve of 'gentlemen' - pastoralists, merchants and professionals such as clergymen, lawyers and doctors - there have always been some women who exerted their influence in their own ways.

From the early 1900s, people began to seek escape from the industrialisation of towns and cities through bushwalking in more remote areas. While the early bushwalking clubs admitted only male members, women were soon knocking on their doors and by the 1920s women were joining these activities and campaigning for the protection of their favoured natural areas.

As these clubs were joined, in the 1950s and 1960s, by national parks associations, National Trust groups and others combining outdoor recreation with campaigns for areas under threat, women continued to play an active role.

By the early 1970s, an unsuccessful campaign to protect Lake Pedder in Tasmania's south-west wilderness and the highly successful Kelly's Bush campaign against inappropriate development in a Sydney harbourside suburb were setting new agendas for environmental protection, with women filling some leadership roles.

The 1980s saw the national campaign against damming of the Franklin River in Tasmania become a touchstone for a whole generation of people who cared about the natural environment. The environment movement gained a strong political voice, in which women took some key roles-initially as volunteers and only later in paid positions.

Since the 1990s, the Federal Government's Ecologically Sustainable Development process, the Decade of Landcare and subsequent developments have seen much more emphasis on partnerships, networks and international environmental initiatives.

The contributions of key women in the evolving environment movement are captured in summary in Table 16.1. 
Table 16.1 The Environment Movement: An evolving force for social change in Australia

\begin{tabular}{|c|c|c|c|c|c|}
\hline $\begin{array}{l}\text { Prior to } \\
\text { Federation }\end{array}$ & Early 1900s & $\begin{array}{c}\text { 1950s \& } \\
1960 s\end{array}$ & 1970s & 1980s & 1990 \& beyond \\
\hline $\begin{array}{l}\text { Gentleman } \\
\text { 'naturalists' }\end{array}$ & $\begin{array}{l}\text { Bushwalking: } \\
\text { respite from } \\
\text { suburbia }\end{array}$ & $\begin{array}{l}\text { Rise of the } \\
\text { 'intellectuals' }\end{array}$ & $\begin{array}{l}\text { Saving special } \\
\text { places }\end{array}$ & $\begin{array}{l}\text { A strong } \\
\text { voice; a } \\
\text { political player }\end{array}$ & $\begin{array}{l}\text { Networks; international } \\
\text { environmentalism; more } \\
\text { forests }\end{array}$ \\
\hline \multicolumn{6}{|c|}{ Women leaders: there from the start } \\
\hline $\begin{array}{l}\text { Supporting } \\
\text { male } \\
\text { colleagues: } \\
\text { Georgiana } \\
\text { Molloy } \\
\text { (1805-43) } \\
\text { Elizabeth } \\
\text { Gould } \\
\text { (1804-41) } \\
\text { Scientific } \\
\text { exploration: } \\
\text { Jane Franklin } \\
\text { (1791-1875) } \\
\text { Ellis Rowan } \\
\text { (1847-1922) } \\
\text { Amalie } \\
\text { Dietrich } \\
\text { (1821-91) } \\
\text { Writing \& } \\
\text { advocating } \\
\text { for the } \\
\text { environment: } \\
\text { Louisa Anne } \\
\text { Meredith } \\
\text { (1812-95) } \\
\text { Louisa } \\
\text { Atkinson } \\
\text { (1834-72) }\end{array}$ & \begin{tabular}{|l|} 
Doing their \\
own walks: \\
Ethel Lun \& \\
two colleagues \\
(1909) \\
Joining male \\
groups: \\
Marie Byles \\
Dorothy \\
Butler (1930s \\
onward) \\
Jessie Luckman \\
(1930s \\
onward) \\
Hattie Clark \\
Advocating \\
for the \\
environment: \\
Irene Longman \\
(1877-1974)
\end{tabular} & $\begin{array}{l}\text { Wildlife } \\
\text { Preservation } \\
\text { Society Qld } \\
\text { (1962-): } \\
\text { Judith Wright, } \\
\text { Kathleen } \\
\text { McArthur \& } \\
\text { David Fleay } \\
\text { Australian } \\
\text { Conservation } \\
\text { Foundation } \\
\text { (1965-): } \\
\text { Penny Figgis } \\
\text { (1970s-) } \\
\text { Tricia Caswell } \\
\text { (1990s) } \\
\text { Little Desert } \\
\text { (1968): } \\
\text { Valerie Honey } \\
\text { \& } \\
\text { Gwynnyth } \\
\text { Taylor }\end{array}$ & $\begin{array}{l}\text { Lake Pedder } \\
\text { (1971-72): } \\
\text { Brenda Hean } \\
\text { \& others } \\
\text { Kelly's Bush } \\
\text { Battlers (1971): } \\
\text { Kath Lehaney } \\
\text { \& other } \\
\text { middle-class } \\
\text { urban residents } \\
\text { Millers Point/ } \\
\text { The Rocks } \\
\text { (1970s-): } \\
\text { Nita McCrae, } \\
\text { Shirley Ball } \\
\text { \& Millicent } \\
\text { Chalmers } \\
\text { (from 1990s) } \\
\text { SW Forests } \\
\text { Defence WA } \\
\text { (1975-): } \\
\text { Beth Schultz } \\
\text { Animal } \\
\text { Liberation } \\
\text { (1976-): } \\
\text { Christine } \\
\text { Townend }\end{array}$ & $\begin{array}{l}\text { Franklin River } \\
\text { (1970s-1982): } \\
\text { Karen } \\
\text { Alexander, } \\
\text { Margaret } \\
\text { Robertson, } \\
\text { Judy Lambert, } \\
\text { Janet Rice, } \\
\text { Linda Parlane, } \\
\text { Christine Milne } \\
\text { Antinuclear } \\
\text { campaigns: } \\
\text { Jo Vallentine } \\
\text { Land Release } \\
\text { Study Group } \\
\text { (WA): } \\
\text { Rosemary } \\
\text { Jasper, Brenda } \\
\text { Newbey \& } \\
\text { Heather Pearce } \\
\text { Australian } \\
\text { Rainforest } \\
\text { Conservation } \\
\text { Society } \\
\text { (1982-): } \\
\text { Aila Keto } \\
\text { NSW } \\
\text { Wilderness Act } \\
\text { (1987): } \\
\text { Margaret } \\
\text { Robertson } \\
\text { Wesley Vale } \\
\text { pulp mill } \\
\text { (1988): } \\
\text { Christine Milne }\end{array}$ & $\begin{array}{l}\text { Federal Ecologically } \\
\text { Sustainable Development } \\
\text { process (early 1990s): } \\
\text { Jane Elix, Imogen Zethoven, } \\
\text { Lyn Goldsworthy } \\
\text { Decade of Landcare } \\
\text { (1990-2000): } \\
\text { Jane Elix, Colma Keating } \\
\text { National Threatened Species } \\
\text { Network: Di Tarte (National } \\
\text { Coord.), Vicki-Jo Russell } \\
\text { (SA Coord.), Peg Putt (Tas } \\
\text { Coord.), Giz Watson (WA } \\
\text { Coord.) } \\
\text { State \& regional } \\
\text { environment groups: } \\
\text { Rachel Siewert (WA } \\
\text { Conservation Council, 16 } \\
\text { years) } \\
\text { Judy Messer (NSW } \\
\text { Conservation Council Chair, } \\
16 \text { years) } \\
\text { Michelle Grady } \\
\text { (Conservation Council of } \\
\text { SA, 12 years) } \\
\text { Liz Bourne, Rosie Crisp, } \\
\text { Imogen Zethoven, Felicity } \\
\text { Wishart (Queensland } \\
\text { Conservation Council } \\
\text { Coordinators, 198Os \& 1990s), } \\
\text { Kelly O'Shannassy (Victoria, } \\
\text { 2011-present) } \\
\text { Maria Mann (Environs } \\
\text { Kimberley, 12 years) } \\
\text { Jill Redwood (East Gippsland } \\
\text { forests, 1980s-present) } \\
\text { Private land acquisition \& } \\
\text { conservation management } \\
\text { (200Os): } \\
\text { Judy Henderson (Bush } \\
\text { Heritage Australia, co- } \\
\text { founder) } \\
\text { Philippa Walsh } \\
\text { International } \\
\text { science-based environmental } \\
\text { NGOs (200Os): } \\
\text { Imogen Zethoven, Michelle } \\
\text { Grady (Pew Trusts) }\end{array}$ \\
\hline
\end{tabular}

Source: Authors' compilation. 
Many of these women did not see themselves as 'leaders' but all were part of an evolving force for social change in Australia.

The women interviewed as part of the Australian Women and Leadership project often said they fell into leadership roles in the environment movement either by filling a gap or by working harder than others. In other words, they saw themselves as 'accidental leaders'.

For example, Margaret Blakers described the way she operates as: 'I see a gapsomething that needs to be done - and then, if I can, I work out how to make it happen.' Brigid Dowsett explains: 'For me, it was never assuming a leadership mantle. It was more being ready and willing to take on responsibility at a certain level and make some decisions about the way I felt things should be managed, or volunteer to do something that no one else was available to do.'

Millicent Chalmers (b. 1934), who has been included on Australia's honours list for her service to the community, is very reluctant to identify herself as a leader. 'I'm really a nursemaid. People say-Millicent will fix it. Millicent will do something.'

Hard work comes through clearly as a strong personal value for many of the women leaders interviewed, and it is to hard work that much of their success as leaders is attributed. Several long-term and well-respected leaders said they work up to 18-hour days almost every day of the week. In some cases, this relates to paid work, in others as a volunteer, and for many it is a mix of both.

Another more emotive driver for these women who are leaders in the environment movement was a sense of outrage at the loss of special places (the 'shared sense of moral outrage' identified by Hutton and Connors). ${ }^{12}$ This sense of outrage turned them into passionate defenders. Long-time Environs Kimberley coordinator Maria Mann was moved to action for the environment because she 'felt a sense of outrage ... at the proposal to dam the Fitzroy River'. Co-founder of The Wilderness Society's Victorian branch Karen Alexander says her involvement was 'built on the anger of the loss of Lake Pedder' . Peace activist and former senator Jo Vallentine described being mobilised by her anger at WA Premier Charles Court's announcement that Western Australia would be the first State in Australia to have a nuclear power plant.

At a deeper level, and consistent with Amanda Sinclair's ${ }^{13}$ observations about the influences of early childhood on our leadership styles and aspirations,

12 Hutton and Connors, A History of the Australian Environment Movement, 5.

13 Sinclair, Leadership for the Disillusioned. 
an early appreciation of the natural environment resulting from bushland experiences or a rural upbringing played an important role for one-third of the women interviewed.

\section{Role models and mentors}

Few of the women interviewed as leaders in the environment movement identified formal mentors, but those who did so felt they had gained significant benefit from the relationships. Several of the interviewees mentioned individuals (both male and female) as role models.

Of the 34 women interviewed, 27 identified one or more aspects of their early life as having influenced their involvement in the environment movement. These factors varied widely, with mothers, fathers and grandmothers identified as important in shaping this aspect of their lives. School and/or teachers were also influential for almost half of the interviewees; for a majority of these women this came from Catholic schools or nuns and the values they imbued in their young charges. Although many of these women later moved away from their Catholic upbringing, the values persisted.

For instance, Colma Keating sees her time at a Catholic school as 'giving her the impetus to think of others, but also understanding that women are not secondrate citizens'. She says the nuns instilled in her 'a sense of being capable of doing things in the world'. Christine Milne reinforces this perception, indicating that her time under the guidance of the nuns imbued her with 'a strong work ethic, a belief that one should have the courage of one's own convictions and a very strong sense of social justice', but also 'a stoic capacity for incredible self-contained resilience'. Jo Vallentine sees her education in Catholic boarding school as 'one contributing factor in my sense of self-identity'. Although from a younger generation, Gemma Tillack also sees her current values as still influenced by the values of community and giving that come from her time growing up in a strong Irish Catholic family.

\section{Female or feminist support groups}

Informal networks such as ad-hoc Green Girls Drinks groups that met informally for breakfast in Canberra or after work in Sydney played an important role for some in demanding positions in the environment movement; however, women in the environment movement have tended not to explicitly emphasise either female or feminist support when they reflect on their experiences. Nor is there evidence of women acting for women as they campaigned for the conservation of special places in Australia's environment. In the interviews conducted for the 
Australian Women and Leadership in a Century of Australian Democracy project, women in the environment movement more frequently focused on conserving the environment for present and future generations - for their children rather than for other women. This is a driver of environmental activism also reported by Yulia Maleta in her study of grassroots activist women in the environment movement. ${ }^{14}$

\section{Critical moments and changes}

The decade from 1983 was a period of substantial gains for the environment movement. This period began with the High Court decision to stop a proposed hydroelectric power supply dam on Tasmania's Franklin River. It included the early 1990s, when the Australian Government showed leadership at the United Nation's Rio Earth Summit, signing on to Agenda 21 and also the Conventions on Biological Diversity and Climate Change. At that time and well into the 1990s, there was a significant, perhaps close to equal, involvement of women in designated leadership positions both at the national level and in State-based peak bodies. The previous gender imbalance in recognised leadership of the movement has, however, returned.

Despite the significant contribution the environment movement has made to social change in Australia, it is today just as male dominated in its recognised leadership as it was in the late 1980s. In 2011, men outnumbered women 7:1 in the (executive) director positions of the conservation councils - the peak bodies for environment groups in each State and Territory. At the same time in 2011, there was only one female CEO among the four major national environment groups: the Australian Conservation Foundation, The Wilderness Society, Greenpeace and the Worldwide Fund for Nature (WWF). The environment movement is more inclusive of women in its board positions, the major national organisations variously having between 18 per cent and 36 per cent women compared with 8.4 per cent in industry and 34 per cent on government-controlled boards. ${ }^{15}$ It is, however, important to recognise that while industry pays its board members and governments generally provide some financial recompense for their work, those on the boards of environment organisations fill voluntary positions. As in government and industry, the environment movement's involvement of women in identified leadership positions has a long way to go before equality is achieved.

14 Yulia Maleta, 'Activism as a Barrier and Gender Dynamics within Australian Third-Sector Environmentalism', Third Sector Review 13(1) (2012): 77-98.

15 Government of Australia, Women Towards Equality (Canberra: Department of Foreign Affairs and Trade, 2011). 
Nevertheless, many women in the environment movement-including many younger women-provide significant leadership outside the mainstream perspectives embodied in the concept of 'transactional' leadership. For these women, social influence directed to accomplishing a common task is achieved through the collaborative approaches characteristic of 'transformational' leadership.

Some have moved into Greens politics (Christine Milne, Rachel Siewert, Giz Watson, Janet Rice, Margaret Blakers), others into international and national philanthropic organisations operating in Australia but not generally seen as part of Australia's environment movement (for example, Imogen Zethoven and Philippa Walsh) and some (Karen Alexander, Judy Lambert, Judy Henderson) into more collaborative local and regional environmental initiatives, frequently working closely with local government and younger women in local communities.

It is in these other areas, rather than in the mainstream environment movement, that these women see leverage for the greatest level of change for their efforts; however, at a time when the environment movement faces increased pressure from the resources and other sectors and from government agendas, it is important that the contribution of women to the movement's leadership is also strengthened.

As Sinclair identifies: 'Only by challenging the assumptions on which leadership is based will we be equipped to seriously anticipate the "transformation" so often promised by leadership. ${ }^{16}$

\section{Acknowledgments}

Jane would not have allowed this chapter to go to publication without an expression of appreciation to the wonderful women who made this project possible by giving generously of their time and experiences. Logistical support from Heather Pearce throughout the project is also greatly appreciated.

\section{References}

Australian Bureau of Statistics (ABS). Australian Social Trends. ABS Publication 4102.0. Canberra: Australian Bureau of Statistics, 2008.

Government of Australia. Women Towards Equality. Canberra: Department of Foreign Affairs and Trade, 2011.

16 Sinclair, Leadership for the Disillusioned, 33. 
Hutton, Drew and Libby Connors. A History of the Australian Environment Movement. Melbourne: Cambridge University Press, 1999.

Maleta, Yulia. 'Activism as a Barrier and Gender Dynamics within Australian Third-Sector Environmentalism.' Third Sector Review 13(1) (2012): 77-98.

Mueller, Carol. 'Ella Baker and the Origins of "Participatory Democracy".' In The Black Studies Reader, edited by Jaqueline Bobo, Cynthia Hudley and Claudine Michel. New York: Routledge, 2004.

Perkins, Dennis, Margaret Holtman, Paul R. Kessler and Catherine McCarthy. Leadership at the Edge: Leadership Lessons from the Extraordinary Saga of Shackleton's Antarctic Expedition. New York: AMACOM, 2000.

Rosener, Judy R. 'Ways Women Lead.' Harvard Business Review (NovemberDecember 1990): 119-125, Reprint No. 90608.

Sinclair, Amanda. Leadership for the Disillusioned. Sydney: Allen \& Unwin, 2007. 
This text taken from Diversity in Leadership: Australian women, past and present, edited by Joy Damousi, Kim Rubenstein and Mary Tomsic, published 2014 by ANU Press, The Australian National University, Canberra, Australia. 